\title{
Effects of milk fat, unhydrogenated and partially hydrogenated vegetable oils on fat metabolism of growing pigs II. Changes in serum cholesterol and triglyceride levels
}

\author{
ASMo KempPinen, Matti JauhiaInen, VeIKKo KankaRe, JaRmo \\ VALAJA, Timo AlaviUHKola, ANTTI ARO and PIRKKo ANTILA
}

Kemppinen, A., Jauhiainen, M., Kankare, V., Valaja, J., Alaviuhrola, T., Aro, A. \& ANTILA, P. 1993. Effects of milk fat, unhydrogenated and partially hydrogenated vegetable oils on fat metabolism of growing pigs II. Changes in serum cholesterol and triglyceride levels. Agric. Sci. Finl. 2: 15-23. (Department of Food Technology, FIN-00014 University of Helsinki, Finland, National Public Health Institute, Departments of Biochemistry and Nutrition, Agricultural Research Centre of Finland, Food Research Institute, FIN-31600 Jokioinen, Finland and Agricultural Research Centre of Finland, Swine Research Station, FIN-05840 Hyvinkää, Finland.)

Fifty mainly crossbred growing pigs were fed diets composed of a basal feed ( $2 \%$ fat) and supplemented $30 \%$ gross energy in the form of butter oil, cream, low erucic acid rapeseed oil (LEAR), sunflower oil or partially hydrogenated sunflower oil for 88 days in order to evaluate the effects of different food fats on their serum cholesterol and triglyceride levels. The levels of serum total cholesterol in the animals fed butter oil $(3.47 \mathrm{mmol} / \mathrm{l})$ and cream $(3.48 \mathrm{mmol} / \mathrm{l})$ were significantly $(\mathrm{p}<0.001)$ higher than those in the animals given rapeseed oil $(2.97 \mathrm{mmol} / \mathrm{l})$, sunflower oil $(2.97 \mathrm{mmol} / \mathrm{l})$ and hydrogenated sunflower oil $(2.91 \mathrm{mmol} / \mathrm{l})$. The high concentration of trans fatty acids $(36.5 \%)$ in the partially hydrogenated vegetable oil had no influence on the cholesterol levels in comparison to the unhydrogenated vegetable oils. The results seem to confirm that dietary trans fatty acids only have a slight effect on serum cholesterol values when the dietary cholesterol concentration is low. The observed changes between the present dietary treatments were probably due to the different fatty acid compositions of the feed fats used and, partly, due to the different cholesterol levels of the diets.

Key words: cholesterol, trans fatty acids, butter oil, cream, rapeseed oil, sunflower oil

\section{Introduction}

According to the lipid hypothesis, dietary saturated fatty acids increase plasma cholesterol concentrations twice as much as polyunsaturated fatty acids decrease cholesterol concentrations (KEYS et al. 1965). The hypothesis has been criticized because it excludes the influence of monosaturated fatty acids, which have been found to have hypocholes- terolemic effects (MATTSON and GRUNDY 1985). Recently, BONANOME and GRUNDY (1988) demonstrated that dietary stearic acid appears to be as effective as oleic acid in lowering plasma cholesterol. The domestic pig is regarded as a good animal model for studying the effects of dietary fats on plasma cholesterol and lipid levels because its response to high fat or high cholesterol diets closely resembles that of humans (MARSH et al. 1972). Pigs 
not only develop spontaneous atherosclerosis with age, but are also susceptible to atherosclerotic plaque formation induced by dietary manipulation (KRITCHEVSKY 1975). In addition, the major classes of swine plasma lipoproteins (VLDL, LDL, HDL) are considered to be very similar to those of human plasma (CHAPMAN 1980). There are numerous studies (e.g. HUTAGALUNG et al. 1969, JACKSON et al. 1977, BALDNER-SHANK et al. 1987, KIM et al. 1989, FAIDLEY et al. 1990) on the hyperlipidemic influence of dietary fats in pigs. However, very few of them (KIM et al. 1989) have dealt with either butter oil or low erucic acid rapeseed oil, which are the most commonly used food fats produced in Finland.

The objective of our study was to determine the effects of dietary milk fat, hydrogenated vegetable oil and unhydrogenated vegetable oils on the triglyceride and the cholesterol values in porcine serum. We were also interested in evaluating the suitability of the domestic pig as an animal model for human nutritional studies. The study was carried out in cooperation with the National Public Health Institute, the Agricultural Research Centre, the National Veterinary Institute, the University of Helsinki, the Raisio Group and the Valio Finnish Co-operative Dairies' Association. The results on the effects of the presently employed feed fats on the growth of the pigs and on the fatty acid composition of their adipose tissue are available elsewhere (SUOMI et al. 1993).

\section{Material and methods}

\section{Experimental animals}

Fifty mainly crossbred (Yorkshire x Landrace) growing pigs of a total of 75 experimental animals were included in blood tests. The experiment was carried out in two trials, one started in January 1990, and the other in September 1990, with twenty-five pigs in each trial. The pigs were allotted to five dietary treatments (five pigs/diet in the both trial) for 88 days. The diets consisted of a basal feed ( $2 \%$ fat) and a $30 \%$ gross energy supplement in the form of added fat or oil. The housing and feeding arrangements, composition of the basal feed and information on the breed, sex and weight of the pigs have been described in detail by SUOMI et al. (1993).

\section{Experimental fats and oils}

The intake of dietary fats and oils was adjusted so as to resemble the human dietary recommendations. Butter oil $(=\mathrm{BO})$, cream $(=\mathrm{CR}, 40$ weight $\%$ fat), low erucic acid rapeseed oil (=RO, LEAR), sunflower oil (=SO) and partially hydrogenated sunflower oil (=HSO) were added to the basal diet. The fatty acid compositions of the basal feed and the added fats and oils are given in Table 1. Butter oil was chosen to represent commonly used saturated food fats (SAFA). Cream was regarded as a useful choice because it contains considerable amounts of membrane material which have been found to have hypocholesterolemic effects in some human studies (HOWARD and MARKS 1979, ANTILA et al. 1980). Rapeseed oil (LEAR) represented a food fat with a high concentration of monounsaturated fatty acids (MUFA) and sunflower oil represented a food fat with a high content of polyunsaturated fatty acids (PUFA). Both MUFA and PUFA have been found to be hypocholesterolemic in the human diet (KeYs et al. 1965, MATTSON and GRUNDY 1985, VALSTA et al. 1992). Partially hydrogenated sunflower oil was chosen in order to study the influence of trans fatty acids on serum lipids.

The cholesterol contents of the experimental diets are given in Table 2 . The cholesterol contents in the different dietary treatments were not equalized. A slight amount of the cholesterol $(0.014 \%$ $w / w)$ found in the vegetable oil diets was derived from fat free milk powder ( $37 \mathrm{mg}$ cholesterol/100 g). The daily cholesterol content of the milk fat diets was equivalent to an addition of ca. $0.057 \%$ $(w / w)$ cholesterol into the feed.

\section{Blood collection and analysis}

Samples were collected from the vena jugularis 
Table 1. Fatty acid compositions of basal feed and feed fats.

\begin{tabular}{lllllll}
\hline Fatty acid & $\mathrm{BO}^{1}$ & $\mathrm{CR}$ & $\mathrm{RO}$ & $\begin{array}{c}\text { SO } \\
\%\end{array}$ & $\begin{array}{c}\mathrm{HSO} \\
(\mathrm{w} / \mathrm{w})\end{array}$ & BF \\
\hline
\end{tabular}

\section{Spring 1990}

$\begin{array}{lll}\mathrm{C} 4 & 3.7 & 3.6\end{array}$

$\begin{array}{lll}\mathrm{C} 6 & 2.3 & 2.4\end{array}$

$\begin{array}{lll}\mathrm{C} 8 & 1.4 & 1.4\end{array}$

$\begin{array}{lll}\mathrm{C} 10 & 2.9 & 3.1\end{array}$

$\begin{array}{lll}\mathrm{C} 12 & 3.1 & 3.4\end{array}$

$\begin{array}{lll}\mathrm{C} 14 & 10.4 & 11.7\end{array}$

$\begin{array}{lll}\text { C16 } & 24.9 & 30.0\end{array}$

C16:1 $1.4 \quad 1.6$

C18

C18 trans

C18:1 cis

C18:2 trans

C18: cis

C18:3

unsaturated

saturated

$13.4 \quad 11.6$

$2.5 \quad 1.4$

$24.5 \quad 21.7$

0.3

2.5

0.3

1.9

0.6

0.4

33.5

66.5

29.3

0.06

3.5

0.2

1.4

1.4

57.4

23.2

10.0

$$
0.1
$$

6.2

0.1

4.3

$\begin{array}{lll} & 0.2\end{array}$

34.0

$23.5 \quad 37.4$

37.4
0.8

$\begin{array}{lll}63.4 & 1.0 & 52.0\end{array}$

$\begin{array}{rrr}63.4 & 1.0 & 52.0 \\ 1.2 & 0.2 & 6.6\end{array}$

\section{Autumn 1990}

C4

$\begin{array}{ll}3.8 & 3.8\end{array}$

C6

$\begin{array}{ll}3.6 & 2.7\end{array}$

$\mathrm{C} 8$

$\mathrm{C} 10$

$\mathrm{C} 12$

$\mathrm{C} 14$

C16

C16:1

$\mathrm{C} 18$

C18:1 trans

C18:1 cis

C18:2 trans

C18:2 cis

C18:3

unsaturated

saturated

$1.5 \quad 1.6$

$3.1 \quad 3.4$

$3.2 \quad 3.6$

$11.0 \quad 11.7$

0.03

$\begin{array}{ll}0.03 & 0.04\end{array}$

$25.6 \quad 30.0$

0.04

3.4

$0.1 \quad 0.1$

0.2

$\begin{array}{lll}6.1 & 7.4 & 18.8\end{array}$

$\begin{array}{lll}0.1 & 0.02 & 0.1\end{array}$

$\begin{array}{llllll}12.3 & 10.5 & 1.5 & 4.2 & 20.5 & 1.4\end{array}$

$\begin{array}{lll}2.7 & 1.7 & 37.9\end{array}$

$\begin{array}{lllll}22.7 & 20.3 & 56.8 & 26.2 & 31.0\end{array}$

$0.3 \quad 0.2$

$1.7 \quad 1.6$

$0.6 \quad 0.4$

22.8

$60.1 \quad 1.0$

$11.9-1.7-7.3$

$\begin{array}{llllll}32.1 & 28.7 & 94.1 & 88.2 & 70.9 & 78.7\end{array}$

$\begin{array}{llllll}67.9 & 71.3 & 5.9 & 11.8 & 29.1 & 21.3\end{array}$

${ }^{1}$ BO = Butter Oil, CR $=$ Cream $(40 \%)$, RO = Low Erucic Acid Rapeseed Oil, SO = Sunflower Oil, HSO = Partially Hydrogenated Sunflower Oil, BF = Basal Feed

into 10-15 ml dry glass serum tubes after at least an 18-h fast. Serum was separated after clotting by low speed centrifugation $(3000 \mathrm{rpm}, 20 \mathrm{~min})$ at room temperature and stored at $+4{ }^{\circ} \mathrm{C}$ until cholesterol and triglyceride analysis. Plasma cholesterol and lipid levels were monitored at baseline, after 6 weeks and at the end of the 88-day feeding period. Serum total cholesterol and high density lipoprotein cholesterol (HDL-c) were determined enzymatically (RösCHLAU et al. 1974). Before the
Table 2. Daily amounts of basal feed, feed fats and cholesterol in the experimental diets during the feeding period.

\begin{tabular}{|c|c|c|c|c|}
\hline \multirow{2}{*}{$\begin{array}{l}\text { Time } \\
\text { (week) }\end{array}$} & \multirow{2}{*}{$\begin{array}{c}\text { Basal feed } \\
\mathrm{kg} / \mathrm{d}\end{array}$} & \multirow{2}{*}{$\begin{array}{c}\text { Feed fat } \\
\mathrm{kg} / \mathrm{d}\end{array}$} & \multicolumn{2}{|c|}{ Cholesterol } \\
\hline & & & $\begin{array}{c}\text { Milk fat } \\
\text { Groups } \\
\text { mg/d }\end{array}$ & $\begin{array}{c}\text { Vegetable fat } \\
\text { Groups } \\
\mathrm{mg} / \mathrm{d}\end{array}$ \\
\hline 0 & 0.67 & 0.11 & 381 & 96 \\
\hline 1 & 0.80 & 0.13 & 451 & 114 \\
\hline 2 & 0.94 & 0.16 & 548 & 114 \\
\hline 3 & 1.07 & 0.18 & 619 & 153 \\
\hline 4 & 1.21 & 0.20 & 691 & 173 \\
\hline 5 & 1.34 & 0.22 & 761 & 191 \\
\hline 6 & 1.47 & 0.25 & 858 & 210 \\
\hline 7 & 1.61 & 0.27 & 929 & 230 \\
\hline 8 & 1.74 & 0.29 & 1000 & 249 \\
\hline $9-13$ & 1.88 & 0.31 & 1072 & 269 \\
\hline
\end{tabular}

HDL-c determination, B-lipoproteins were precipitated as described by KOSTNER (1976). The triglyceride concentration was determined according to the method of WAHLEFELD (1974). Very low density lipoprotein (VLDL) and low density lipoprotein (LDL) were isolated from the serum samples by ultracentrifugation at $\mathrm{d}<1.006 \mathrm{~g} / \mathrm{ml}$ and $1.006-$ $1.063 \mathrm{~g} / \mathrm{ml}$ according to the method of HAVEL et al. (1955). VLDL- and LDL-c were determined by the method of RösCHLAU et al. (1974).

\section{Statistical analysis}

Statistical analysis of the data was performed by the analysis of variance using the GLM procedure of SAS (1985). The cholesterol and triglyceride compositions were examined by a split plot analysis of variance with repeated measures as outlined by GILL and HAFS (1971). Trial, sex and diet were considered as the main plot effects and the sampling times of the blood samples as the subplot effects. The following model was used:

$Y_{i j k l m n}=\mu+E_{i}+T_{j}+S_{k}+T_{j k}+e_{i j k l}+P_{m}+T_{j m}$ $+\mathrm{SP}_{\mathrm{km}}+\mathrm{e}_{\mathrm{ijk} k \mathrm{mn}}$

where $\mathrm{Y}_{\mathrm{ijklmn}}$ is the dependent variable; $\mu$ is the the overall mean; $E_{i}$ is the effect of the trial $(i=1,2) ; T_{j}$ is the effect of the treatment $(j=1, \ldots, 5) ; S_{k}$ is the 
Table 3. Average lipid and lipoprotein levels of growing pigs fed butter oil (BO), cream (CR), low erucic acid rapeseed oil (RO), sunflower oil (SO) or partially hydorgenated sunflower oil (HSO).

\begin{tabular}{lrrrrrrrrrr}
\hline Component & \multicolumn{4}{c}{$\begin{array}{c}\text { Dietary treatments } \\
\text { 30 \% fat added as }\end{array}$} & \multicolumn{3}{c}{ SEM $^{1}$} & \multicolumn{3}{c}{ Statistical significance $^{2}$} \\
& BO & \multicolumn{1}{c}{ CR } & \multicolumn{1}{c}{ RO } & SO & HSO & & Cl $^{3}$ & C2 & C3 & C4 \\
\hline Total cholesterol, mmol/L & 3.03 & 3.03 & 2.75 & 2.78 & 2.72 & 0.088 & $* * *$ & NS & NS & NS \\
& $(10)^{4}$ & $(10)$ & $(8)$ & $(10)$ & $(10)$ & & & & & \\
HDL cholesterol, mmol/L & 1.22 & 1.35 & 1.15 & 1.26 & 1.25 & 0.086 & $* *$ & NS & NS & 0 \\
& $(10)$ & $(10)$ & $(9)$ & $(10)$ & $(10)$ & & & & & \\
LDL cholesterol, mmol/L & 1.28 & 1.33 & 1.24 & 1.24 & 1.29 & 0.094 & NS & NS & NS & NS \\
& $(10)$ & $(9)$ & $(9)$ & $(10)$ & $(10)$ & & & & & \\
VLDL cholesterol, mmol/L & 0.085 & 0.087 & 0.082 & 0.081 & 0.077 & 0.0088 & NS & NS & o & NS \\
& $(10)$ & $(9)$ & $(9)$ & $(10)$ & $(10)$ & & & & & \\
Triglyceride, mmol/L & 0.75 & 0.77 & 0.71 & 0.74 & 0.84 & 0.078 & NS & NS & $*$ & NS \\
& $(10)$ & $(10)$ & $(10)$ & $(10)$ & $(10)$ & & & & & \\
\hline
\end{tabular}

\footnotetext{
${ }^{1} \mathrm{SEM}=$ standard error of means.

${ }^{2}$ Statistical significance: $\mathrm{NS}=$ nonsignificant, $\mathrm{o}=\mathrm{P}<0.10,{ }^{*}=\mathrm{P}<0.05$, $* *=\mathrm{P}<0.01,{ }^{*} * *=\mathrm{P}<0.001$.

${ }^{3}$ Contrasts: $\mathrm{C} 1=$ vegetable fats $(\mathrm{RO}, \mathrm{SO}, \mathrm{HSO})$ vs. milk fats $(\mathrm{BO}, \mathrm{CR}), \mathrm{C} 2=\mathrm{BO}$ vs. $\mathrm{CR}, \mathrm{C} 3=\mathrm{SO}$ vs. HSO, C4 = RO vs. $\mathrm{SO}$.

${ }^{4}$ Number of samples analysed.
}

effect of the sex $(k=1,2)$ and $P_{m}$ is the effect of sampling time $(\mathrm{k}=1,2,3)$. $\mathrm{e}_{\mathrm{ijkl}}$ is the error term for the main plot effect and $e_{i j k l m n}$ is the error term for the subplot effects. The sums of squares of the treatment effects were further partitioned into four orthogonal contrasts, $\mathrm{Cl}$ : vegetable fats (the sum of the effects of RO, SO and HSO) vs milk fat (the sum of the effects of $\mathrm{BO}$ and $\mathrm{CR}$ ); $\mathrm{C} 2$ : $\mathrm{BO}$ vs CR; C3: SO vs HSO; C4: RO vs SO.

\section{Results and discussion}

One animal in the $\mathrm{RO}$ group died during the feeding period in spring but there was no indication that the death was directly due to the experimental arrangements. In general, the animals were in good health and their growth was normal throughout the experimental period regardless of the higher proportion of lipids in their feed compared to the normal swine diet.

The serum total cholesterol concentrations (Figure 1) increased in all feeding groups during the experimental period. The increases were $37 \%$, $35 \%, 16 \%, 9 \%$ and $9 \%$ in the $\mathrm{BO}, \mathrm{CR}, \mathrm{RO}, \mathrm{SO}$ and HSO groups, respectively, as calculated from the initial cholesterol levels. The cholesterol concen- trations of the milk fat groups (BO, CR) were significantly $(\mathrm{p}<0.001)$ higher than those of the other feeding groups (Table 3 ). No differences were found between the vegetable fat groups (BO, SO, HSO) or, on the other hand, between the two milk fat groups (Table 3 ). The same trends were evident after 6 weeks (Figure 1), which agreed with other studies where changes in swine total cholesterol levels were detectable already after 3-5 weeks (Pownall et al. 1980, Walsh Hentges et al. 1985, BALDER-SHANK et al. 1987).

Elevations in serum total cholesterol level due to the increased portion of fat or oil in the swine diet were in agreement with previous studies carried out with moderate amounts of fat and cholesterol (HutAGAlung et al. 1969, JACKSON et al. 1977, BALDNERSHANK et al. 1987). Extreme elevations have been detected when high amounts $(>1 \%)$ of cholesterol have been added into the diet. POWNALL et al. (1980) demonstrated that beef tallow supplemented with $1.5 \%, 2 \%$ or $2.5 \%$ (w/w) of cholesterol increased the total cholesterol levels to $7.1 \mathrm{mmol} / \mathrm{l}(275 \mathrm{mg} / \mathrm{dl})$ after a 9-week feeding period. KIM et al. (1989) found that feed containing over $40 \%$ of energy as butter and ca. $2 \%$ of energy $(10 \mathrm{~g} / \mathrm{d})$ as cholesterol increased the serum cholesterol level as high as $21 \mathrm{mmol} / \mathrm{l}(816 \mathrm{mg} / \mathrm{dl})$. Some 


\section{Serum Total Cholesterol}

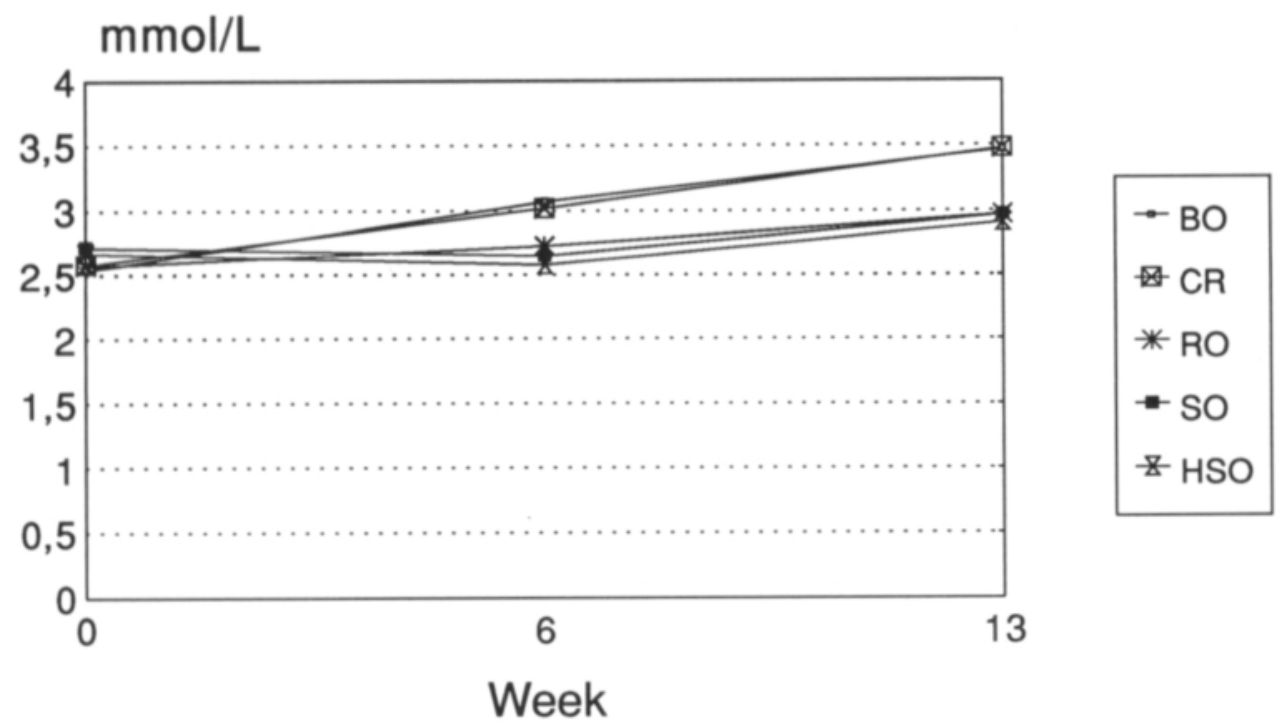

\section{HDL Cholesterol}

\section{$\mathrm{mmol} / \mathrm{L}$}

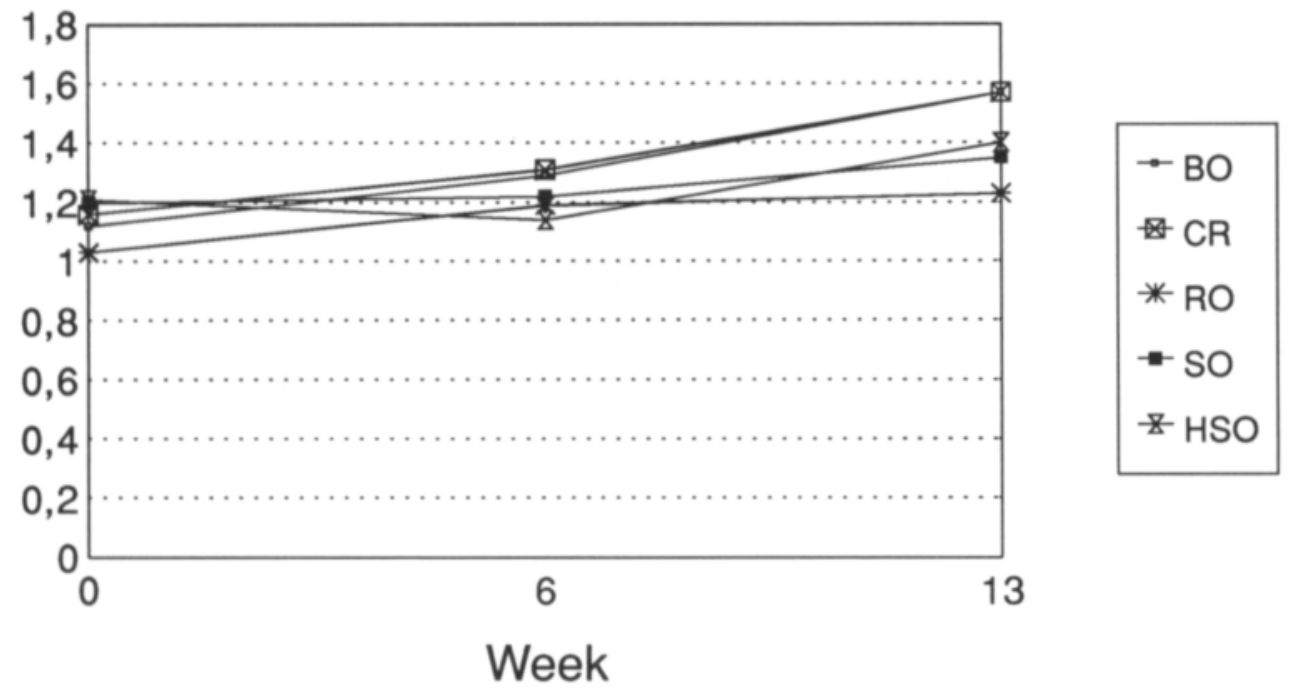

Fig. 1. Total cholesterol and high density lipoprotein cholesterol (HDL) concentrations (mmol/L) in growing pigs fed butter oil (BO), cream (CR), low erucic acid rapeseed oil (RO), sunflower oil (SO) and partially hydrogenated sunflower oil (HSO) at baseline after 6 weeks and after 13 weeks. 
controversial findings concerning the hypercholesterolemic effect of animal fats on swine have been reported recently. In the experiments carried out by HARTOG et al. (1987) with lard, and by FAIDLEY et al. (1990) with tallow as the feed fat showed no increase in total cholesterol levels.

Our results seem to support the general lipid hypothesis on the hypercholesterolemic effects of long-chain saturated fatty acids (C12:0C16:0). However, the elevations of total cholesterol levels induced by milk fat were moderate compared to the findings of KIM et al. (1989), which was obviously due to the lower dietary cholesterol intake used in our study. The almost identical cholesterol levels of the pigs in the $\mathrm{BO}$ and $\mathrm{CR}$ groups indicated that the membrane material of cream did not induce any detectable hypocholesterolemic effect on porcine serum. The present results agree with a recent study on human subjects (SALMELA et al. 1990).

We did not notice any elevation of total cholesterol in the pigs fed hydrogenated vegetable oil (36.5\% of trans fatty acids on average) compared to the pigs fed unhydrogenated vegetable oil. This finding was in agreement with the studies of JACKSON et al. (1977) who found that total cholesterol was at the same level in pigs fed tallow and hydrogenated fish oil (HFO), but showed a slight increase when $\mathrm{HFO}$ was supplemented with cholesterol. JACKSON and his co-workers suggested that only small differences could be induced in total cholesterol when low concentrations of cholesterol are used in a diet containing trans fatty acids. In some human studies, trans fatty acids were shown to be hypercholesterolemic (e.g. MENSINK and KATAN 1990).

The HDL cholesterol (HDL-c) concentrations (Figure 1) increased $40 \%, 34 \%, 19 \%, 13 \%$ and $16 \%$ in the $\mathrm{BO}, \mathrm{CR}, \mathrm{RO}, \mathrm{SO}$ and $\mathrm{HSO}$ groups, respectively, as calculated from the baseline levels. The HDL-c level was significantly higher $(\mathrm{P}<0.01)$ in the pigs fed milk fat than that in the pigs fed vegetable oils (Table 3). No statistically significant changes were found in the LDL- and VLDL-cholesterol concentrations between the feeding groups (Table 3). No marked changes were detected between the feeding groups in the ratio of HDL cholesterol to total serum cholesterol (Table 4), indicat-
Table 4. The ratio of high density lipoprotein (HDL) to total serum cholesterol (TOTCHOL) in growing pigs fed butter oil (BO), cream (CR), low erucic acid rapeseed oil (RO), sunflower oil (SO) and partially hydrogenated sunflower oil (HSO) at baseline, after 6 weeks and after 13 weeks.

\begin{tabular}{cccccc}
\hline Week & & \multicolumn{4}{c}{ HDL/TOTCHOL } \\
& BO & CR & RO & SO & HSO \\
\hline 0 & 0.44 & 0.45 & 0.40 & 0.44 & 0.45 \\
6 & 0.42 & 0.43 & 0.44 & 0.46 & 0.44 \\
13 & 0.45 & 0.45 & 0.41 & 0.45 & 0.48 \\
\hline
\end{tabular}

ing that most of the the increase in total cholesterol is due to the increase in HDL cholesterol.

KIM et al. (1989) also noticed a slight increase in the HDL cholesterol levels of pigs fed butter, although the main increase was in the cholesterol levels in the LDL1 fraction consisting of large LDL molecules. Our results were contrary to some human studies (MATTSON and GRUNDY 1985, MENSINK and KATAN 1990), in which the addition of saturated fats resulted in an elevation of LDL cholesterol levels while HDL cholesterol remained mostly unaffected. Small and dense LDL particles are considered to be the most atherogenic lipoprotein molecules in human plasma (AUSTIN et al. 1990). However, KIM et al. (1989) showed atherogenic influences of large LDL particles containing $\mathrm{B}$ and $\mathrm{E}$ apoproteins in pigs. They based their findings on atherosclerotic lesion development in the coronary arteries and aorta of pigs fed milk fat and cholesterol. Pigs fed a diet containing high concentrations of cholesterol have been demonstrated to have less dense and larger LDL-particles than pigs receiving a low cholesterol diet (HILL et al. 1975, POWNALL et al. 1980).

The triglyceride content of the pigs in the HSO feeding group was significantly higher $(\mathrm{P}<0.05)$ than that of the SO feeding group (Table 3 ). No significant differences were found between the milk fat groups and vegetable oil groups, however. The moderate increase in triglycerides observed by Hutagalung et al. (1969) in pigs fed a diet containing saturated animal fats (tallows) could not be confirmed in this study. 


\section{Conclusions}

The pigs fed butter oil or cream had markedly higher serum total cholesterol levels than the pigs fed low erucic acid rapeseed oil, sunflower oil or partially hydrogenated sunflower oil. The same trend was also observed in the total HDL-c levels, although the differences between the dietary treatments were not as obvious. The elevation in the cholesterol values could have been due to the different fatty acid composition of the dietary fats and, partially, to the comparatively higher cholesterol content of the feed of the milk fat groups.

The high concentration of trans fatty acids $(36.5 \%)$ in the partially hydrogenated vegetable oil did not influence the cholesterol levels in compari- son to the unhydrogenated vegetable oils. Our results seem to confirm that the effect of dietary trans fatty acids on porcine serum cholesterol is small when the dietary cholesterol concentration is low.

Domestic pigs can be regarded as a sound animal model in human studies, as far as the influences of dietary fat on serum total cholesterol values and triglyceride values are concerned. However, more controversial results were found in HDL cholesterol concentrations in comparison to human studies.

Acknowledgements. The financial support provided by the Academy of Finland is gratefully acknowledged. The authors thank the Raisio Group and the Valio Finnish Cooperatives Dairies' Association for donating the food fats and oils used in our study.

\section{References}

Antila, M., Ali-Yrkkö, S., Antil.a, V., Antula, P., RönneMAA, T., JÄrVEl ÄINEN, H. \& ViIKARI, J. 1980. Is fat globule membrane essential for cholesterol lowering effect of milk? Lancet I: 602 .

Austin, M. A., King, M. C., Vranizan, K. M. \& Krauss, R. M. 1990. Atherogenic lipoprotein phenotype. Circulation 82: 495-506.

Baldner-Shank, G. L., Richard, M. J., Bertz, D. C. \& JacobSON, N. L. 1987. Effect of animal and vegetable fats and proteins on distribution of cholesterol in plasma and organs of young growing pigs. J. Nutr. 117: 1727-1733.

BonANOME, A \& GRUNDY, S. M. 1988. Effect of dietary stearic acid on plasma cholesterol and lipoprotein levels. N. Engl. J. Med. 318: 1244-1248.

Chapman, M. J. 1980. Animal lipoproteins: chemistry, structure, and comparative aspects. J. Lipid Res. 21: 789-854.

GiLl. J. L. \& HAFS, H. D. 1971. Analysis of repeated measurements of animals. J. Anim. Sci. 33: 331-336.

Faidley, T. D., Luhman, C. M., Galloway, S. T., Foley, M. K. \& Berrz, D. C. 1990. Effect of dietary fat source on lipoprotein composition and plasma lipid concentrations in pigs. J. Nutr. 120: 1126-1133.

Hartog, J. M., Verdouw, P. D., Klompe, M. \& Lamers, J. M. J. 1987. Dietary mackerel oil in pigs: Effect on plasma lipids, cardiac sarcolemmal phospholipids and cardiovascular parameters. J. Nutr. 117: 1371-1378.

Havel, R. J., Eder, H. A. \& Bragdon, H. J. 1955. The distribution and chemical composition of ultracentrifugally separated lipoproteins in human serum. J. Clin. Invest. 34: 1345-1353.

Hill. E. G., Silbernick, C. L. \& Lindgren, F. 1975. Development of hyperbetalipoproteinemia in pigs fed atherogenic diet. Lipids 10: 41-43.
Howard, A. N. \& MarKs, J. 1979. Effect of milk products on serum-cholesterol. Lancet II: 957.

Hutagalung, R. I., Cromwell, G. L., Hays, V. W. \& Chaney, C. H. 1969. Effect of dietary fat, protein, cholesterol and ascorbic acid on performance, serum and tissue cholesterol levels and serum lipid levels of swine. J. Anim. Sci. 29: 700-705.

Jackson, R. L., Morrisett, J. D., Pownall, H. J., Gotto, A. M. Jr., Kamio, A., Imai, H., Tracy, R. \& Kummerow, F. A. 1977. Influence of dietary trans-fatty acids on swine lipoprotein composition and structure. J. Lipid Res. 18: 182-190.

Keys, A., Anderson, J. T. \& Grande, F. 1965. Serum cholesterol response to change in the diet. Part IV. Particular saturated fatty acids in the diet. Metabolism 14: 776-787.

Kim, D. N., Ho, H.-T., Lawrence, D. A., Schmee, J. \& ThoMAS, W. A. 1989. Modification of lipoprotein patterns and retardation of atherogenesis by a fish oil supplement to a hyperlipidemic diet for swine. Atherosclerosis 76: 35-54.

KostNer, G. M. 1976. Enzymatic determination of cholesterol in high density lipoprotein fraction prepared by polyanion precipitation. Clin. Chem. 22: 695-701.

KRITCHEVSKY, D. 1975. Animal models for atherosclerosis research. In: Kritchevsky, D. (ed.). Hypolipidemic Agents. Springer-Verlag, Berlin. p. 214.

Marsh, A., Kim, D. N., Lee, K. T., Reiner, J. M. \& Thomas, W. A. 1972. Cholesterol turnover, synthesis and retention in hypercholesterolemic growing swine. J. Lipid Res. 13: 600-615.

Mattson, F. H. \& Grundy, S. M. 1985. Comparison of effects of dietary saturated, monounsaturated, and polyunsaturated fatty acids on plasma lipids and lipoproteins in man. J. Lipid Res. 26: 194-202. 
Mensink, R. P. \& Katan, M. B. 1990. Effect of dietary trans fatty acids on high-density and low-density lipoprotein cholesterol levels in healthy subjects. N. Engl. J. Med. 323: 439-335.

Pownal., H. J., Jackson, R. L., Roth, R. I., Gotto, A. M., Patsch, J. R. \& Kummerow, F. A. 1980. Influence of an atherogenic diet on the structure of swine low density lipoproteins. J. Lipid Res. 21: 1108-1115.

Röschlau, P., Bernt, E. \& Gruber 1974. Enzymatische bestimmung des gesamtcholesterins in serum. Z. Klin. Chem. Klin. Biochem. 12: 406-409.

Salmel.a, M., Taittonen, M., Antila, K., Vitikari, J., Antilla, P., Antila, V., Kankare, V. \& Pahkala, E. 1990. The effect of cream on plasma cholesterol. Milchwissenschaft 45: 760-762.

SAS 1985. SAS User's Guide: Statistics. 5 th Ed. SAS Institute Inc, Cary, NC, USA. 956 p.

Suomi, K., Alaviuhkola, T., Valaja, J., Kankare, V. \& KempPINEN, A. 1993. Effects of Milk Fat, Unhydrogenated and Partially Hydrogenated Vegetable Oils on Fat Metabolism of Growing Pigs. I Growth, Feed Utilization and Carcass Quality in Pigs Fed Different Fats and Oils. Agric. Sci. Finl. 2: 7-13.

Valsta, L. M., Jauhiainen, M., Aro, A., Katan, M. B. \& MutANEn, M. 1992. Effects of a monounsaturated rapeseed oil and a polyunsaturated sunflower oil diet on lipoprotein levels in humans. Arteriosclerosis and Thrombosis 12: 50-57.

WAHLEFeld, A. W. 1974. Triglycerides. Determination after enzymatic hydrolysis. In: Bergmeyer H. U. (ed.). Methods of enzymatic analysis. New York. Acad Pres. p. 18-31.

Walsh Hentges, L. S., Bertz, D. C., Jacobson, N. L., McGil. LIARD, A. D. \& VeEnhuizen, J. J. 1985. Cholesterol Transport and uptake in miniature swine fed vegetable and animal fats and proteins. 1. plasma lipoproteins and LDL clearance. Lipids 20: 735-742.

\section{Manuscript received June 1992}

Asmo Kemppinen, Pirkko Antila

Department of Food Technology/Dairy Science

P.O. Box 27 (Viikki B)

FIN-00014 University of Helsinki, Finland

Matti Jauhiainen, Antti Aro

National Public Health Institute

Departments of Biochemistry and Nutrition

Mannerheimintie 166

FIN-00300 Helsinki, Finland

Veikko Kankare

Agricultural Research Centre of Finland

Food Research Institute

FIN-31600 Jokioinen, Finland

Timo Alaviuhkola

Agricultural Research Centre of Finland

Swine Research Station

FIN-05840 Hyvinkää, Finland

Jarmo Valaja

Agricultural Research Centre of Finland

Swine Research Station

FIN-05840 Hyvinkää, Finland

Present adress:

Department of Animal Science

P.O. Box 28

FIN-00014 University of Helsinki, Finland 


\title{
SELOSTUS
}

\section{Maitorasvan, kasviöljyjen ja osittain hydratun kasviöljyn vaikutukset lihasikojen rasva-aineenvaihduntaan II Muutokset seerumin kolesteroli- ja triglyseridiarvoissa}

\author{
ASMo KempPinen, Matti Jauhiainen, VeikKo KankaRe, JaRmo \\ Valaja, Timo AlaviUhKola, ANTti Aro ja PirKKo ANTILA \\ Helsingin yliopisto, Kansanterveyslaitos ja Maatalouden tutkimuskeskus
}

\begin{abstract}
Maitorasvan, kerman, rypsiöljyn, auringonkukkaöljyn ja osittain hydratun auringonkukkaöljyn vaikutuksia seerumin kolesteroliin ja triglyserideihin tutkittiin viidelläkymmenellä koesialla (pääasiassa risteytyseläimiä). Porsaille syötettiin 88 vuorokauden ajan perusrehua ( $2 \%$ rasvaa), johon oli lisätty koerasvoja tai -öljyjä $30 \%$ bruttoenergiasta.

Maitorasvaa saaneilla sioilla seerumin kokonaiskolesterolipitoisuus oli $3,47 \mathrm{mmol} / \mathrm{l}$ ja kermaryhmän sioilla 3,48 $\mathrm{mmol} / \mathrm{l}$ kokeen lopussa. Arvot olivat merkitsevästi $(\mathrm{P}<0,001)$ korkeammat kuin rypsiöljy- (2,97 mmol/l), auringonkukkaöljy- $(2,97 \mathrm{mmol} / \mathrm{l})$ tai hydratun auringonkukkaöljyryhmän (2,91 mmol/l) sioilla. Osittain hydratun auringonkukkaöljyn
\end{abstract}

korkealla trans-rasvahappopitoisuudella $(36,5 \%)$ ei todettu vaikutusta seerumin kolesteroliarvoihin. Tulos näyttäisi vahvistavan käsitystä, että dieetin trans-hapot vaikuttavat seerumin kolesteroliarvoihin vain vähän, jos dieetin kolesterolipitoisuus on alhainen. Maitorasvaa saaneiden sikojen kolesterolipitoisuus nousi myös HDL-fraktiossa, mutta ero kasvirasvaryhmien sikoihin ei ollut tilastollisesti yhtä selvä $(\mathrm{P}<0,01)$ kuin kokonaiskolesteroliarvoissa. Sekä koerasvojen rasvahappokoostumuksen erot että dieettien erilaiset kolesterolipitoisuudet olivat todennäköisesti syynä havaittuihin kolesteroliarvojen eroihin koeryhmien välillä. 